\title{
Pemanfaatan jagung (Zea mays) sebagai bahan tambahan dalam pembuatan permen Jelly
}

\author{
Utilization of corn (Zea mays) as additional materials in making the jelly candy
}

\author{
Raden Rizki Amalia ${ }^{1)}$, Ema Lestari ${ }^{1 *}$,Nia Erika Safitri ${ }^{1)}$ \\ ${ }^{1}$ Jurusan Teknologi Industri Pertanian, Politeknik Negeri Tanah Laut, \\ Tanah Laut, Kalimantan Selatan \\ *Email korespondensi: emalestari@politala.ac.id \\ Informasi artikel: \\ Dikirim: 16/07/2020; disetujui: 10/10/2020; diterbitkan: 30/03/2021
}

\begin{abstract}
Candy is a snack that is loved by many people, especially children because it has a sweet taste. The texture of the candy is divided into hard candy (hard candy) and soft candy (soft candy). One example of soft candy is jelly candy. Jelly is a candy made from water or plant juice and gel-forming material. The material that can be used in making jelly candy is juice from corn. Corn is a cereal crop that contains starch or sugar, this corn is usually needed in the industrial world as feed or in the food processing industry. The purpose of this study was to produce corn jelly candy products favored by panelists through hedonic testing, hedonic quality, moisture content, ash content, and $\mathrm{pH}$ in accordance with SNI (Indonesian National Standard). This research method is experimental with the addition of corn juice in the manufacture of jelly candy with formulations of 0 grams, 90 grams, 100 grams, and 110 grams, then tested the level of preference (hedonic), hedonic quality, water content, ash content, and acidity. The results showed that the best formulation was 110 grams with hedonic values of color, texture, aroma, and flavor parameters which were highly favored by the panelists, hedonic quality values were very rubbery, the aroma was very flavorful typical of corn and the taste was very corny. Value of water content of $7.80 \%$, ash content of $0.33 \%$, and $\mathrm{pH}$ or acidity level 6.
\end{abstract}

Keywords: corn, candy quality, jelly candy

\begin{abstract}
ABSTRAK
Permen adalah makanan ringan yang disukai banyak masyarakat terutama anak-anak, karena memiliki rasa manis. Tekstur permen terbagi atas permen keras (hard candy) dan permen lunak (soft candy). Salah satu contoh permen lunak adalah permen jelly. Permen jelly merupakan permen yang dibuat dari air atau sari buah tanaman dan bahan pembentuk gel. Bahan yang dapat digunakan dalam pembuatan permen jelly yaitu sari dari jagung. Jagung merupakan tanaman serealia yang mengandung pati maupun gula, jagung ini biasanya diperlukan dalam dunia industry sebagai pakan maupun dalam industri pengolahan makanan. Tujuan penelitian ini adalah menghasilkan produk permen jelly jagung yang disukai panelis melalui uji hedonik, mutu hedonik, kadar air, kadar abu, dan pH sesuai dengan SNI (Standart Nasional Indonesia). Metode penelitian ini adalah eksperimental dengan penambahan sari jagung pada pembuatan permen jelly dengan formulasi 0 gram, 90 gram, 100 gram, dan 110 gram, kemudian diuji tingkat kesukaan (hedonik), mutu hedonik, kadar air, kadar abu dan kadar keasaman. Hasil penelitian menunjukkan bahwa formulasi terbaik yaitu 110 gram dengan nilai hedonik
\end{abstract}


parameter warna, tekstur, aroma, dan rasa sangat disukai panelis, nilai mutu hedonik tekstur sangat kenyal, aroma sangat beraroma khas jagung dan rasa sangat terasa jagung. Nilai kadar air 7,80\%, kadar abu 0,33\%, dan $\mathrm{pH}$ atau derajat keasaman 6 .

Kata kunci: jagung, kualitas permen, permen jelly

\section{PENDAHULUAN}

Permen adalah makanan ringan yang disukai banyak masyarakat terutama anakanak, karena memiliki rasa manis di lidah ketika dihisap dan dikunyah. Umumnya permen yang beredar dikalangan masyarakat yaitu permen keras (hard candy) dan permen lunak (soft candy). Permen keras adalah permen yang padat teksturnya dan permen lunak adalah permen yang memiliki tekstur lunak dan kenyal. Permen jelly termasuk permen lunak (soft candy) yang dibuat dari sari buah dan bahan pembentuk gel, kenampakan jernih dan transparan, serta mempunyai tekstur dan kekenyalan tertentu (Koswara, 2009).

Salah satu contoh permen lunak adalah permen jelly. Permen jelly merupakan permen yang dibuat dari air atau sari buah tanaman dan bahan pembentuk gel. Permen jelly berpenampilan jernih dan transparan serta mempunyai tekstur yang elastis dengan kekenyalan tertentu. Aneka rasa dan bentuk permen jelly yang banyak beredar di pasaran saat ini biasanya disebut dengan istilah soft jelly candy (Huda et al., 2015).

Bahan pembentuk gel yang biasa digunakan antara lain gelatin, karagenan, dan agar-agar (Bactiar et al., 2013). Adanya kandungan karagenan rumput laut secara fungsional dapat berfungsi sebagai penstabil, pengental, dan pembentuk gel sehingga dapat mempengaruhi karakteristik produk pangan khususnya permen jelly. Salah satu sari yang dapat digunakan dalam pembuatan permen jelly yaitu sari dari jagung.

Jagung merupakan salah satu tanaman serealia yang berpotensi untuk dikembangkan sebagai produk pangan fungsional karena jagung mengandung asam amino esensial, mineral, serat pangan, asam lemak esensial, dan lainnya yang diperlukan oleh tubuh (Suarni dan Yasin, 2019) dan di Indonesia, jagung merupakan komoditas yang dibutuhkan untuk banyak industri, baik industri pakan maupun dalam industri pengolahan makanan. Menurut data USDA, konsumsi jagung di kawasan Asia Pasifik saat ini $60 \%$ untuk pakan ternak, $30 \%$ untuk makanan manusia, dan $10 \%$ untuk biofuel. Konsumsi jagung di Indonesia lebih dari $55 \%$ digunakan untuk kebutuhan pakan, sedangkan konsumsi pangan hanya $30 \%$ dan selebihnya untuk industri lainnya. Semakin berkembangnya industri pengolahan jagung, maka permintaan komoditas jagung di kalangan masyarakat juga akan meningkat hal ini membuka peluang bagi petani untuk meningkatkan produksi jagung (Paeru dan Dewi, 2017).

Kandungan jagung dalam bentuk pati maupun gula yang relatif tinggi dapat digunakan sebagai bahan baku dalam produk fermentasi. Di beberapa negara maju, jagung telah diusahakan dalam berbagai olahan dalam bentuk emping dan tortilla, atau dibuat krim, dan sebagai minuman dalam bentuk susu jagung maupun yoghurt. Berdasarkan uraian yang ada di atas, perlu adanya penambahan inovasi baru produk olahan berbahan baku jagung yaitu dengan memanfaatkan jagung sebagai bahan tambahan dalam pembuatan permen jelly. Hal ini dapat memvariasikan jagung menjadi produk permen jelly, sehingga jagung dapat dimanfaatkan secara maksimal dan menjadi produk olahan yang bernilai ekonomis tinggi.

Juliyanti, et al. (2018)melakukan penelitian Pembuatan Permen Jelly Menggunakan Ubi Jalar Ungu (Ipomoea batatas L.) Dengan Penambahan Berbagai Konsentrasi Virgin Coconut Oil (VCO) dan Emulsfier Tween 80, Efendi, et al. (2019) juga melakukan penelitian tentang Pembuatan Permen Jelly Dari Wortel dan Bonggol Nanas. Namun belum ada yang melakukan penelitian menganai pembuatan permen jelly dari jagung. Produk permen 
jelly jagung ini dapat berpotensi sebagai peluang usaha. Selain manfaatnya, bahan baku yang alami dan mudah didapat, produk permen jelly juga digemari oleh anak-anak hingga orang dewasa. Permen jelly jagung ini dapat dijadikan sebagai cara orang tua untuk mengantisipasi para anak-anak yang tidak menyukai buah maupun sayur terutama jagung.

\section{METODE}

Penelitian ini dilaksanakan dari Maret hingga Juli 2019 meliputi pembuatan produk sampai pengujian di Laboratorium Teknonogi Pangan Politeknik Negeri Tanah Laut. Metode penelitian ini adalah eksperimental dengan penambahan sari jagung pada pembuatan permen jelly dengan formulasi 0 gram, 90 gram, 100 gram, dan 110 gram.

Alat

Alat yang digunakan dalam pembuatan permen jelly jagung ini adalah timbangan, kompor, pisau, blender, baskom, panci, spatula, dan nampan.

\section{Bahan}

Bahan yang digunakan dalam pembuatan permen jelly jagung ini adalah sari jagung, gula pasir, air, dan gelatin.

\section{Metode/ pelaksanaan}

\section{Pembuatan sari jagung}

Adapun pembuatan sari buah jagung pada penelitian ini berdasarkan penelitian sebelumnya oleh (Yulianti et al., 2018) yaitu jagung yang digunakan disortasi dan dipilih buah yang tidak terkontaminasi. Selanjutnya jagung dibersihkan dengan air mengalir selanjutnya ditiriskan. Kemudian disisir jagungnya dan ditimbang sebanyak 300 gram dan ditambahkan air sebanyak 300 gram, selanjutnya jagung diblender selama 3 menit. Setelah diblender jagung dituang ke dalam penyaringan, kemudian disaring menggunakan kain saring hingga diperoleh sari jagung, kemudian sari jagung ditimbang.

\section{Pembuatan permen jelly}

Adapun pembuatan permen jelly jagung pada penelitian ini berdasarkan penelitian sebelumnya oleh (Yulianti et al., 2018) yaitu ditimbang sari jagung menjadi 3 formulasi (90 g, $100 \mathrm{~g}$, dan $110 \mathrm{~g}$ ). Sari jagung yang sudah ditimbang kemudian ditambahkan air 100 gram, gula 200 gram sesuai masing-masing formulasi. Sebelum ditambahkan gelatin, gelatin terlebih dulu dilarutkan kedalam 100 gram air panas. Selanjutkan dicampurkan bahan-bahan seperti sari jagung, gula, dan air kemudian diaduk bahan-bahan tersebut sampai tercampur rata. Selanjutnya dimasukkan gelatin yang sudah dilarutkan. Setelah semua bahan tercampur dengan rata, kemudian dimasak selama 50 menit. Kemudian setelah 50 menit adonan dituangkan dalam cetakan dan didinginkan selama 24 jam pada suhu ruang. Selanjutnya permen jelly dikeluarkan dari cetakan lalu dipotong sesuai ukuran yang telah ditentukan. Permen yang telah dipotong dilumuri gula sebanyak \pm 30 gram dan siap dikemas

Formulasi yang digunakan yaitu dengan membuat tiga perbandingan bahan yang berbeda. Perbandingan dapat dilihat pada Tabel 1 di bawah ini.

Tabel 1. Perbandingan formulasi pada pembuatan permen jelly jagung

\begin{tabular}{ccccc}
\hline Perlakuan & Sari jagung (\%) & Gula (gram) & Gelatin (gram) & Air (gram) \\
\hline F1 & 0 & 200 & 20 & 100 \\
F2 & 22 & 200 & 20 & 100 \\
F3 & 24 & 200 & 20 & 100 \\
F4 & 26 & 200 & 20 & 100 \\
\hline
\end{tabular}

\section{Uji hedonik}

Uji hedonik pada penelitian ini dilakukan dengan cara yaitu disiapkan permen jelly jagung dipiring kecil dan diletakkan di meja. Disiapkan 30 panelis dalam satu ruangan. Panelis melakukan uji hedonik yang meliputi tingkat kesukaan. Adapun skala dalam penilaian uji 
hedonik yaitu bisa dilihat pada Tabel 2 dibawah ini.

Tabel 2. Skala uji hedonik

\begin{tabular}{cl}
\hline Skala & Tingkat kesukaan \\
\hline 1 & Amat sangat tidak suka \\
2 & Sangat tidak suka \\
3 & Tidak suka \\
4 & Agak tidak suka \\
5 & Netral \\
6 & Agak suka \\
7 & Suka \\
8 & Sangat suka \\
9 & Amat sangat suka \\
\hline
\end{tabular}

Berdasarkan Tabel 2 skala tingkat kesukaan yang sesuai dengan Standar Nasional Indonesia (SNI) adalah memiliki skala angka 1 sampai 9. Skala angka tertinggi yaitu 9 dengan tingkat kesukaan amat sangat suka. Skala terendah yaitu 1

Tabel 3. Skala uji mutu hedonik

\begin{tabular}{cccc}
\hline Skala & Tekstur & Aroma & Rasa \\
\hline 1 & Amat sangat tidak & Amat sangat tidak beraroma & Amat sangat tidak terasa \\
khas jagung & jagung \\
2 & Sangat tidak kenyal & Sangat tidak beraroma khas & jagung \\
3 & Tidak kenyal & Tidak beraroma khas jagung & Tidak terasa jagung \\
4 & Agak tidak kenyal & Agak tidak beraroma khas & Agak tidak terasa jagung \\
5 & Netral & jagung & Netral \\
6 & Agak kenyal & Agak beraroma jagung & Agak terasa jagung \\
7 & Kenyal & Beraroma jagung & Terasa jagung \\
8 & Sangat kenyal & Sangat beraroma jagung & Sangat terasa jagung \\
9 & Amat sangat kenyal & Amat sangat beraroma & Amat sangat terasa jagung \\
\hline
\end{tabular}

Berdasarkan Tabel 3 skala uji mutu hedonik yang sesuai dengan Standar Nasional Indonesia (SNI) adalah memiliki skala angka 1 sampai 9. Skala angka tertinggi yaitu 9, sedangkan skala terendah yaitu 1 .

\section{Uji kadar air}

Berdasarkan SNI 3547-2-2008 produk permen jelly disyaratkan mempunyai kadar air maksimal 20\%. Pengujian kadar air pada penelitian ini dilakukan dengan cara yaitu dipanaskan cawan dalam oven pada suhu $100^{\circ} \mathrm{C}$ selama \pm 1 jam dan didinginkan dalam desikator selama 30 menit kemudian ditimbang dengan neraca analitik $\left(\mathrm{W}_{0}\right)$. Dimasukkan 5 dengan tingkat kesukaan amat sangat tidak suka.

\section{Uji mutu hedonik}

Uji mutu hedonik pada penelitian ini dilakukan dengan cara yaitu disiapkan permen jelly jagung di piring kecil dan piring itu diletakkan di atas meja. Permen jelly terlebih dulu dilakukan penentuan warna menggunakan aplikasi corel draw. Permen jelly yang sudah jadi kemudian difoto, hasil gambar yang diperoleh dimasukkan ke dalam aplikasi corel draw. Setelah sudah dapat warnarnya kemudian gambar di screenshot. Kemudian disiapkan 30 panelis dalam satu ruangan. Panelis melakukan uji mutu hedonik yang meliputi aroma, rasa, dan tekstur. Adapun skala dalam penilaian uji mutu hedonik yaitu bisa dilihat pada Tabel 3 di bawah ini. gram sampel permen jelly kedalam cawan dan ditimbang $\left(\mathrm{W}_{1}\right)$. Dipanaskan cawan yang berisi sampel di dalam oven pada suhu $100^{\circ} \mathrm{C}$ selama \pm 3 jam, kemudian cawan dipindahkan ke dalam desikator dan didinginkan selama 30 menit kemudian ditimbang $\left(\mathrm{W}_{2}\right)$. Selanjutnya dihitung kadar air permen jelly jagung menggunakan rumus berikut.

$$
\text { Uji kadar Air }=\frac{\mathrm{W} 1-\mathrm{W} 2}{\mathrm{~W} 1-\mathrm{W} 0} \times 100 \%
$$

\section{Keterangan:}

$\mathrm{W}_{1}=$ berat sampel dan cawan sebelum dioven (gr)

$\mathrm{W}_{2}=$ berat sampel dan cawan sesudah dioven (gr)

$\mathrm{W}_{0}=$ berat cawan kosong $(\mathrm{gr})$

Sumber: SNI 3547-2-2008 


\section{Uji kadar abu}

Berdasarkan SNI 3547-2-2008 produk permen jelly disyaratkan mempunyai kadar abu maksimal 3,0\%. Pengujian kadar abu pada penelitian ini dilakukan dengan cara ditimbang cawan kosong dengan neraca analitik $\left(\mathrm{W}_{0}\right)$. Dimasukkan sampel sebanyak 3-5 gram ke dalam cawan dan ditimbang $\left(\mathrm{W}_{1}\right)$. Ditempatkan cawan berisi sampel tersebut dalam tanur pada suhu $550^{\circ} \mathrm{C}$ sampai terbentuk abu berwarna putih selama 5 jam. Dipindahkan segera ke dalam desikator dan didinginkan selama 30 menit kemudian ditimbang $\left(\mathrm{W}_{2}\right)$. Selanjutnya dihitung kadar abu permen jelly jagung menggunakan rumus sebagai berikut.

$$
\text { Uji kadar Abu }=\frac{\mathrm{W} 2-\mathrm{W} 0}{\mathrm{~W} 1-\mathrm{W} 0} \times 100
$$

Keterangan:

$\mathrm{W}_{1}=$ berat sampel dan cawan sebelum diabukan (gr)

$\mathrm{W}_{2}=$ berat sampel dan cawan sesudah diabukan (gr)

$\mathrm{W}_{0}=$ berat cawan kosong $(\mathrm{gr})$

Sumber : SNI 3547-2-2008

\section{Uji kadar keasaman (pH)}

Pengujian kadar keasaman $(\mathrm{pH})$ dilakukan dengan disiapkan 3 sampel dengan masing-masing perlakuan, sampel yang diambil yaitu sampel yang masih encer dan belum membeku. Setelah pengambilan sampel kemudian disiapkan kertas uji $\mathrm{pH}$ dan kertas dicelupkan pada sampel. Hasil yang diperoleh dicocokkan pada pengukuran derajat keasaman yang ada pada kertas pengukuran.

\section{HASIL DAN PEMBAHASAN}

Berdasarkan hasil penelitian pemanfaatan jagung (Zea mays) sebagai bahan tambahan dalam pembuatan permen jelly didapatkan hasil formulasi permen jelly jagung sebagai berikut:

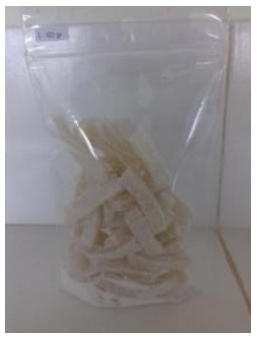

Gambar (a)

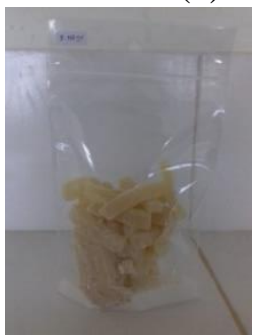

Gambar (c)

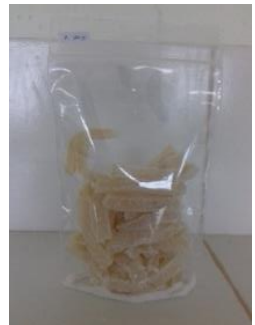

Gambar (b)

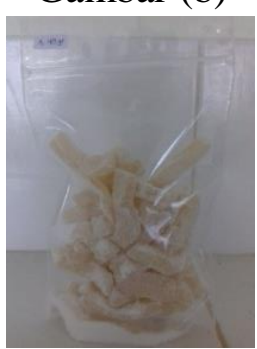

Gambar (d)
Gambar 1. Permen Jelly (a) tanpa sari jagung, (b) dengan sari jagung 90 gram, (c) dengan sari jagung 100 gram, dan (d) dengan sari jagung 110 gram

Tabel 4. Hasil perhitungan uji hedonik

\begin{tabular}{|c|c|c|c|c|c|}
\hline \multirow{2}{*}{ Formulasi } & & \multicolumn{4}{|c|}{ Parameter permen jelly jagung } \\
\hline & & Warna & Tekstur & Aroma & Rasa \\
\hline \multirow[t]{3}{*}{ F1 } & Interval nilai & $8,01 \leq \mu \leq 8,30$ & $8,01 \leq \mu \leq 8,25$ & $8,02 \leq \mu \leq 8,27$ & $8,03 \leq \mu \leq 8,29$ \\
\hline & Nilai akhir & 8,01 dibulatkan & 8,01 dibulatkan & 8,02 dibulatkan & 8,03 dibulatkan \\
\hline & & 8 (sangat suka) & 8 (sangat suka) & 8 (sangat suka) & 8 (sangat suka) \\
\hline \multirow[t]{3}{*}{$\mathrm{F} 2$} & Interval nilai & $7,97 \leq \mu \leq 8,32$ & $8,02 \leq \mu \leq 8,25$ & $8,07 \leq \mu \leq 8,27$ & $8,01 \leq \mu \leq 8,27$ \\
\hline & Nilai akhir & 7,97 dibulatkan & 8,02 dibulatkan & 8,04 dibulatkan & 8,01 dibulatkan \\
\hline & & 8 (sangat suka) & 8 (sangat suka) & 8 (sangat suka) & 8 (sangat suka) \\
\hline \multirow[t]{3}{*}{ F3 } & Interval nilai & $8,01 \leq \mu \leq 8,27$ & $8,06 \leq \mu \leq 8,28$ & $8,08 \leq \mu \leq 8,32$ & $8,04 \leq \mu \leq 8,27$ \\
\hline & Nilai akhir & 8,01 dibulatkan & 8,06 dibulatkan & 8,08 dibulatkan & 8,04 dibulatkan \\
\hline & & 8 (sangat suka) & 8 (sangat suka) & 8 (sangat suka) & 8 (sangat suka) \\
\hline \multirow[t]{3}{*}{$\mathrm{F} 4$} & Interval nilai & $8,01 \leq \mu \leq 8,27$ & $8,05 \leq \mu \leq 8,30$ & $8,11 \leq \mu \leq 8,33$ & $8,04 \leq \mu \leq 8,27$ \\
\hline & Nilai akhir & 8,01 dibulatkan & 8,05 dibulatkan & 8,11 dibulatkan & 8,04 dibulatkan \\
\hline & & 8 (sangat suka) & 8 (sangat suka) & 8 (sangat suka) & 8 (sangat suka) \\
\hline
\end{tabular}

Pengujian organoleptik adalah pengujian yang didasarkan pada proses pengindraan. Uji organoleptik yang dilakukan adalah uji scoree sheet yang terdiri dari uji hedonik dan uji mutu hedonik terhadap aroma, rasa, warna dan tekstur. Pengujian dilakukan oleh 30 panelis.

Uji hedonik adalah pengujian terhadap suatu produk dengan cara meminta tanggapan dari panelis mengenai kesukaan 
atau tidak suka. Beberapa formulasi yang digunakan setelah dilakukan uji hedonik terhadap panelis maka didapatkan hasil perhitungan dari masing-masing panelis bahwa permen jelly dengan perlakuan F1, F2, F3, dan F4 sangat disukai panelis berdasarkan warna, tekstur, aroma, dan rasa. Selanjutnya permen jelly jagung perlakuan F4 merupakan formulasi terbaik berdasarkan penilaian panelis terhadap warna, tekstur, aroma, dan rasa panelis karena memiliki skor lebih tinggi dibandingkan lainnya.

Tabel 5. Hasil uji mutu hedonik

\begin{tabular}{cccccc}
\hline \multirow{2}{*}{$\begin{array}{c}\text { Paramet } \\
\text { er }\end{array}$} & & \multicolumn{4}{c}{ Perlakuan } \\
\cline { 3 - 5 } & & F1 & F2 & F3 & F4 \\
\hline Warna & Pantone $656 \mathrm{C}$ & Pantone 450 C & Pantone 455 C & Pantone 463 C \\
\hline \multirow{2}{*}{ Tekstur } & Nilai akhir & 7,93 dibulatkan & 7,95 dibulatkan & 7,96 dibulatkan & 8,02 dibulatkan \\
& & 8 (sangat kenyal) & 8 (sangat kenyal) & 8 (sangat kenyal) & 8 (sangat kenyal) \\
\hline \multirow{2}{*}{ Aroma } & Interval nilai & $7,93 \leq \mu \leq 8,13$ & $7,95 \leq \mu \leq 8,14$ & $7,96 \leq \mu \leq 8,18$ & $8,03 \leq \mu \leq 8,22$ \\
& Nilai akhir & 7,93 dibulatkan & 7,95 dibulatkan & 7,96 dibulatkan & 8,02 dibulatkan \\
& & 8 (sangat kenyal) & 8 (sangat kenyal) & 8 (sangat kenyal) & 8 (sangat kenyal) \\
\hline \multirow{2}{*}{ Rasa } & Interval nilai & $2,98 \leq \mu \leq 3,13$ & $7,96 \leq \mu \leq 8,15$ & $7,99 \leq \mu \leq 8,17$ & $8,02 \leq \mu \leq 8,24$ \\
& Nilai akhir & 2,98 dibulatkan & 7,96 dibulatkan & 7,99 dibulatkan & 8,02 dibulatkan \\
& & 3 (tidak terasa & 8 (sangat terasa & 8 (sangat terasa & 8 (sangat terasa \\
& & jagung) & jagung) & jagung) & jagung) \\
\hline
\end{tabular}

Uji mutu hedonik yaitu uji hedonik yang lebih spesifik yang biasanya bertujuan untuk mengetahui respon panelis terhadap sifat mutu organoleptik. Berdasarkan hasil uji mutu hedonik permen jelly berdasarkan beberapa perlakuan bahwa F1 memiliki warna pantone $656 \mathrm{C}$, tekstur sangat kenyal, tidak beraroma khas jagung, dan tidak terasa jagung.

Tabel 6. Hasil nilai rata-rata pengujian kadar air, kadar abu, dan $\mathrm{pH}$

\begin{tabular}{|c|c|c|c|c|c|c|}
\hline \multirow{2}{*}{ Pengujian } & \multicolumn{4}{|c|}{ Perlakuan } & \multirow{2}{*}{$\begin{array}{c}\text { Standar } \\
\text { SNI } 3547-2-2008\end{array}$} & \multirow{2}{*}{ Keterangan } \\
\hline & $\mathrm{F} 1$ & $\mathrm{~F} 2$ & F3 & F4 & & \\
\hline Kadar air \% & 7,24 & 11,64 & 13,15 & 7,80 & $\leq 20 \%$ & Memenuhi SNI \\
\hline Kadar abu \% & 0,28 & 0,29 & 0,27 & 0,33 & $\leq 3,0 \%$ & Memenuhi SNI \\
\hline $\mathrm{pH}$ & 6 & 6 & 6 & 6 & 4,78 & Tidak memenuhi SNI \\
\hline
\end{tabular}

Kadar air sangat mempengaruhi terhadap mutu dari permen, karena tingkat keawetan permen mempunyai hubungan yang erat dengan kadar air yang dikandungnya. Suatu bahan pangan harus memiliki kadar air rendah sehingga dapat disimpan dalam jangka waktu lama. Hasil analisis menunjukkan bahwa kadar air ratarata permen berkisar antara $7,12 \%$ sampai dengan 13,15\%. Berdasarkan SNI 35471 2008 tentang kembang gula lunak, kadar air maksimal $20 \%$ maka kadar air dari permen jelly jagung sudah memenuhi syarat mutu.
Kemudian F2 memiliki warna pantone $450 \mathrm{C}$, tekstur sangat kenyal, sangat beraroma khas jagung, dan sangat terasa jagung. Selanjutnya F3 memiliki warna pantone $455 \mathrm{C}$, tekstur sangat kenyal, sangat beraroma khas jagung, dan sangat terasa jagung, sedangkan F4 memiliki warna pantone $463 \mathrm{C}$, tekstur sangat kenyal, sangat beraroma khas jagung, dan sangat terasa jagung. 
terkandung dalam bahan akan berubah. Hal ini didukung juga oleh pendapat Kasim dan Suryani (2010), apabila glukosa ditambahkan ke dalam bahan pangan sebagian dari air yang ada tidak tersedia untuk pertumbuhan mikroorganisme.

Selain itu faktor lain yang menyebabkan tinggi rendahnya kandungan air permen jelly jagung adalah suhu pemasakan, proses pengadukan dan lama pemasakan permen. Menurut Rachmawan (2001), bahwa makin tinggi suhu pemanasan, makin besar energi panas yang dibawa udara sehingga makin banyak jumlah massa air bahan yang diuapkan dari permukaan bahan yang dikeringkan.

Kadar abu adalah zat sisa hasil pembakaran suatu bahan organik. Kadar abu merupakan salah satu parameter penentu mutu dari permen, dimana kadar abu ini mempengaruhi penampakan dari permen (Mandei, 2014). Hasil kadar abu yang diperoleh berkisar antara $0,27 \%$ sampai dengan $0,33 \%$. Tidak ada perbedaan kadar abu yang signifikan antara keempat perlakuan. Kadar abu pada permen jelly yang dihasilkan masih sesuai dengan standar mutu permen jelly SNI 354722008.

Muchtadi (1997) menyatakan proporsi kadar abu dalam suatu bahan pangan dapat juga dipengaruhi oleh beberapa faktor seperti spesies, keadaan unsur hara tanah, keadaan kematangan bahan pangan, iklim, daerah tempat tumbuh dan perlakuan penanaman. Selain itu kadar abu terdiri dari unsur mineral, dalam proses pembakaran, bahanbahan organik terbakar tetapi zat anorganiknya tidak, karena itulah disebut sebagai abu (Winarno, 2008).

Derajat keasaman atau $\mathrm{pH}$ adalah tingkat keasaman atau kebasaan yang dimiliki oleh suatu larutan. Permen jelly jagung memiliki $\mathrm{pH}$ asam. Hal ini dikarenakan adanya perubahan suhu serta penambahan gula. Hasil pH yang diperoleh yaitu 6 hal ini belum memenuhi SNI 013547-1994 yaitu sebesar 4,78. Hal ini dikarenakan pada pembuatan permen jelly jagung tidak ditambahkan asam. Hal tersebut yang menyebabkan $\mathrm{pH}$ permen jelly jagung tidak memenuhi SNI 01-3547-1994. Padahal Menurut Winarno (2008), penambahan asam sitrat dengan jumlah yang kecil juga dapat menurunkan nilai $\mathrm{pH}$. Selanjutnya Muawanah et al. (2012), penambahan asam sitrat akan meningkatkan menambah rasa.

\section{KESIMPULAN}

Berdasarkan hasil penilitian yang dilakukan pada pemanfaatan jagung (Zea mays) sebagai bahan tambahan dalam pembuatan permen jelly maka dapat disimpulkan bahwa formulasi terbaik yaitu F4 dengan nilai hedonik parameter warna, tekstur, aroma, dan rasa sangat disukai panelis, nilai mutu hedonik tekstur sangat kenyal, aroma sangat beraroma khas jagung, dan rasa sangat terasa jagung. Nilai kadar air $7,80 \%$, kadar abu $0,33 \%$, dan $\mathrm{pH}$ atau derajat keasaman 6.

\section{UCAPAN TERIMA KASIH}

Terima kasih kami ucapkan kepada Politeknik Negeri Tanah Laut atas dukungannya dalam penelitian ini.

\section{DAFTAR PUSTAKA}

Bactiar, A., Ali, A., \& Rossi, E. (2013). Pembuatan permen jelly ektrak jahe merah dengan penambahan karagenan. PhD Thesis. Riau University.

Efendi, R., Yurmarini, Y., \& Zulkifli, Z. (2019). Pembuatan permen jelly dari wortel dan bonggol nanas. Seminar Nasional Pembangunan Pertanian Berkelanjutan Berbasis Sumber Daya Lokal, 404-417.

Herawati, H. (2008). Penentuan umur simpan pada produk pangan. Jurnal Litbang Pertanian, 27(4), 124-130.

Huda, S., Sahputra, A., Anggono, W. A., \& Wahyuni, R. (2015). Pemanfaatan daun kersen (muntingia calabura) sebagai permen jelly terhadap daya terima konsumen. Teknologi Pangan: Media Informasi dan Komunikasi 
Ilmiah Teknologi Pertanian, 6(1), 1. https://doi.org/10.35891/tp.v6i1.463

Juliyanti, D., Su'i, M., Sumaryati, E., \& Suprihana, S. (2018). Pembuatan permen jelly menggunakan ubi jalar ungu (Ipomoea batatas L.) dengan penambahan berbagai konsentrasi virgin coconut oil (vco) dan emulsfier tween 80. Agrika, 12(1), 1-11.

Kasim, Y. B., \& Suryani, U. (2010). Uji Konsentrasi Sukrosa dan Sirup Glukosa Terhadap Mutu Permen Keras dari Sari Jagung (Zea Mays. L) dengan Metode Oven Pan. Jurnal Ilmiah Agropolitan, 3, 373-383.

Koswara, S. (2009). Teknologi pembuatan permen. Ebook Pangan, 1-60.

Mandei, J. H. (2014). Komposisi beberapa senyawa gula dalam pembuatan permen keras dari buah Pala. Jurnal Penelitian Teknologi Industri, 6(2), 110.

Muchtadi, T. (1997). Pengolahan hasil pertanian nabati. Jurusan Teknologi Pangan dan Gizi-IPB. Bogor.

Muawanah, A., Djajanegara, I., Sa'duddin, A., \& Sukandar, D. (2012). Penggunaan bunga kecombrang (Etlingera Elatior) dalam proses formulasi permen jelly. Jurnal Kimia Valensi, 2(4).

Paeru, R. H., \& Dewi, T.Q.S. P. (2017). Panduan Praktis budidaya jagung. Penebar Swadaya Grup.

Rachmawan, O. (2001). Pengeringan, pendinginan dan pengemasan komoditas pertanian. Depdiknas. Jakarta.

Standar Nasional Indonesia. (2008). Revisi Kembang Gula Lunak (Jelly) Departemen Perindustrian.

Suarni, S., \& Yasin, M. (2019). Jagung sebagai sumber pangan fungsional.

Winarno, F. G. (2008). Kimia pangan dan gizi: edisi terbaru. Jakarta:Gramedia Pustaka Utama.

Yulianti, Y., Syam, H., \& Sukainah, A. (2018). Pemanfaatan buah tomat (solanum lycopersium) sebagai bahan tambahan dalam pembuatan permen jelly. Jurnal Pendidikan Teknologi

Pertanian, 4, 14-20. 